\title{
Sports Test Model to Measure Athlete's Physical Fitness Through the Application
}

\author{
Iyakrus $^{*}$, and Arizky Ramadhan ${ }^{2}$ \\ ${ }^{12}$ Physical Education Department, Universitas Sriwijaya, Palembang, South Sumatra, Indonesia \\ *Corresponding author's email: iyakrus@fkip.unsri.ac.id
}

\begin{abstract}
The purposes of this study are develop the test model, determine test model effectiveness, and measures the physical abilities of South Sumatera athletes. The method that used in this study is development research methods with a test model to measure the physical ability of athletes using the application. With five procedures, they are product analysis, initial products, expert validation, trials small-scale and broad-scale; product revision and final product. The techniques of data collection in this study using observation guidelines while questionnaires using percentage data analysis techniques and physical test data collection techniques by category. Subjects were 20 South Sumatra athletes. The results shown in explosive power aspect, $15 \%$ athletes are excellent and $85 \%$ athletes are good. The results shown in speed aspect, 30\% athletes are excellent, 65\% athletes are good, and 5\% athletes are fair. The results shown in agility aspect, $15 \%$ athletes are excellent, $75 \%$ athletes are good, and $10 \%$ athletes are fair. The results shown in flexibility aspect, $20 \%$ athletes are excellent, $70 \%$ athletes are good, and $10 \%$ athletes are fair. The results shown in durability aspect, $20 \%$ athletes are excellent, $75 \%$ athletes are good, and 5\% athletes are fair. This model produces an effective physical test component for athletes, it can be suggested for trainers to be able to use this test model as an alternative in measuring the physical abilities of athletes.
\end{abstract}

Keywords: Sports Test Model, Athlete's Physical Fitness

\section{INTRODUCTION}

The important thing in sports is a physical condition. So, the training for physical condition needs to get attention, planned carefully and systematically, then the physical fitness level and the body functional abilities are better. Tests and measurements are an integral part of the process of training results. This is in line with the research that done by Yatar [21], Warbuton [19], and Fagaras [6] that physical activity can improve athletic physical fitness. Through this test we get objective data, so we need measuring tools and expert testors to master the method of measurement [5]. Measurements in sports need to be carried out based on the following principles: Measurements are made to achieve goals according to the scope and types of objectives, and in the measurement process should set goals in advance; The method of measurement in sports is limited to the test only, because the test is one part of the measurement and in reality many things related to sports that have not been measured; The measuring instruments should be valid and reliable measuring devices; Tests and measurements should be carried out by trained and experienced officers in the field [5][8].

The test requires a valid measuring instrument, an adequate test equipment, and an experienced testors. Besides this, with the development of technology in this globalization era, the data needed or the results of a test should use a tool that can measure the physical fitness level of athletes including the whole, the tool is a computer application or can be called software that can record and calculate all test that the athlete follows and knows the physical fitness level of the athlete or VO2 max of each athlete.

The definition of software is stored the electronic data collection and managed by a computer, that electronic data can be program or instruct for execute a command. The command runs by computer through this software.

The model of software can assist the test team in managing data quickly and precisely. The software is expected to reduce the error rate in managing test result data. These phenomena are interesting to study so that this research is conducted to find out whether the athlete's physical test application product can be considered a valid and reliable application. The objects in this study are 20 South Sumatra athletes who will compete at PON XX 2020 in Papua.

The product of this research is physical test model for athletes in the form of application, which is designed and arranged according to the physical component aspects that measure the athlete's physical abilities. 
The formulation of the problem from this research are: How to build a model for test to measure the abilities of physical of athletes using the application model; How the effectiveness of the test model to measure the physical ability of athletes using the application; and How the physical abilities of South Sumatra athletes using the application model. In accordance with the above problem formulation, the objectives of this study are: Develop a test model to measure the physical abilities of athletes using the application model; Knowing the effectiveness of the test model to measure the physical abilities of athletes using the application; and Knowing the physical abilities of athletes in PON XX South Sumatra using the application model.

\section{METHOD}

This study is a study development that is used in solving practical problems in the lines of social science, natural sciences, engineering, and education. Research and development methods are methods for obtaining specific products and testing the products effectivity [10] [18]. Research and development is a process for developing and validating products that can be used in education [12]. Through this research it is hoped that it can bridge the research gap, which is more testing the theory towards producing products and can be used in enhancing the physical components of the PON XX athletes in South Sumatra. The research process was developed using the basic research and development stages builded by Borg and Gall [12] which include ten steps of activities to find the right model.

\section{RESULT AND DISCUSSION}

\subsection{Research Result (The results in a large scale)}

The study process was developed using research and development lines builded by Borg and Gall in Wasis [20], they are: collect research and information, design, build initial form of product, test the initial stage, revise a main product, test the main stage, revise a operational product, test the operational stage, and final product.

After the research steps, the sports product for measuring athletes' physical fitness includes: flexibility, durability, explosion power, agility, and speed. After that, the product is tested on a small scale and then revised, the next step is a large-scale trial.

Table 1. Physical test results of athletes

\begin{tabular}{llllll}
\hline Physical Component & Total & Minimum Score & Maximum Score & Mean Score & Standard Deviation \\
\hline Explosive Power & 20 & 40 & 64 & 50.05 & 7.272696 \\
Speed & 20 & 2.54 & 3.33 & 2.9895 & 0.192093 \\
Agility & 20 & 9.01 & 13.33 & 10.452 & 1.080061 \\
Flexibility & 20 & 33 & 65 & 46.15 & 7.995229 \\
Durability & 20 & 7.8 & 11.8 & 9.61 & 1.199956 \\
\hline
\end{tabular}

Table 1 shows the research results on a component of flexibility, durability, explosion power, agility, and speed in a large scale. Data of physical test results are distributed in the frequency diagram.

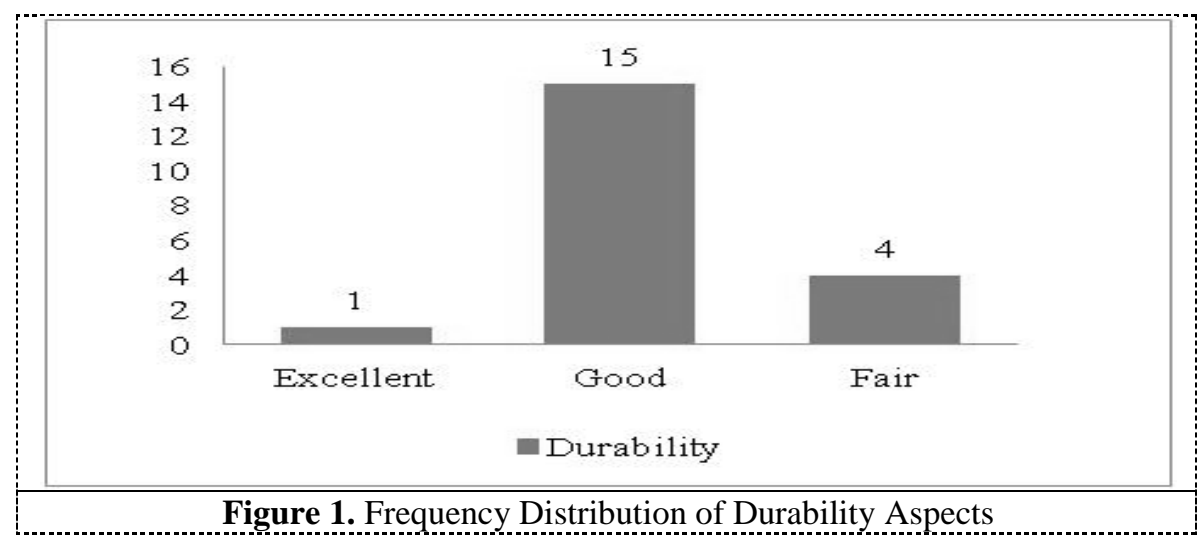

Figure 1 shows that 15 athletes or $75 \%$ are in excellent category, while 4 athletes or $20 \%$ are in good category and 1 athlete or $5 \%$ is in fair category.

\subsection{Research Result Explanation}

1.3. The physical test model for athletes is a test model that develops the physical aspects of players in 
sports, namely the physical aspects of explosive power, speed, agility, flexibility and durability. This physical test model is in line with Hanif's opinion [2], the shape and the method of physical test is very depend on the component that trained, so it is important to know the physical components in sports [10]. Then, the stage to start a test program is based on the results of a physical test according to the conditioning phase which develops the physical aspects of the athlete in the sport concerned [14]. Based on Iyakrus [4], physical test that suitable with the athletes requirement in the ground will be capable support the appearance of athletes, giving rise to self-confidence during the competition.

Development is a process to be better, while the model is a pattern that will be created. Development is a process towards physical and age improvement [11]. Thus, the development of a model is a process of activities to create patterns of change that are better than before. The model is defined as a conceptual framework that is used as a guide in carrying out activities [13]. Based on the above opinion, which is related in this study, what is meant by the physical test application model for athletes is a procedural framework of physical tests that is systematically arranged, designed, and developed to achieve goals, specifically measuring the ability in components of physical which include explosive power, speed, agility, flexibility and durability. Physical fitness is absolutely necessary for athletes because physical fitness conditions determine achievement [3]. Therefore the level of physical fitness must always be monitored by conducting regular physical fitness tests. Guided by sport science, we need preliminary data from the level of physical fitness before the training period is arranged [11][4]. Then in Balsevich [1] and Trudeau [17] opinions, sports coaches really need data from physical test results, which will be used as a basis for the purpose of developing an effective training program. Therefore, this model test is extremely needed for coach to monitoring their athletes physical condition.

\section{CONCLUSION}

From the results and analysis of the research obtained several conclusions. In a form of test, this model is based on the needs of athletes physical components and include tests of speed, explosion power, flexibility, durability, and agility designed in a steps of physical test. The physical test model through the application has a good effectiveness in measuring the physical components of athletes which is increase the physical components of flexibility, durability, explosion power, agility, and speed of athletes. This study produced a physical test model through application and can be used to measuring the physical components of athletes in any field. Some suggestions given and related to the use of this product are: in measuring the athlete's physical components, coaches can use this product model and researchers expect input and suggestions from users to improve this physical model to be more perfect.

\section{REFERENCES}

[1] Balsevich, V. (2006). Sports vector of physical education in the Russian schools: monograph. Moscow: Theory and Practice of Physical Culture and Sports, $326 \mathrm{p}$.

[2] Bompa O T 2009 Total Training for Young Champions (Champaign: Human Kinetics)

[3] Bray, S.R., Born, H.A. (2004). Transition to university and vigorous physical activity: Implications for health and phychological wellbeing. Journal of American College Health, 52(4):181-188. Doi:10.3200/JACH.52.4.181-188.

[4] Darst, P. W. (2014). Dynamic physical education for secondary school students. Pearson, $152 \mathrm{p}$

[5] El-Gylany, A.H., Badawi, K., El-Khawaga, G., \& Awadalla, N. (2011). Physical activity profile of students in Mansoura University, Egypt. Eastern Mediterranean Health Journal, 17(8):694-702.

[6] Fagaras, S.P., Radu, L.E., Vanvu, G. (2015). The Level of Physical Activity of University Students. Procedia - Social and Behavioral Sciences, 197 1454 - 1457. Online: 2 Desember 2019:

[7] Fox 2009 Physiological Basis Of Physical Education and Athletics (Philadelphia: 4th Ed Saunders College Publishing)

[8] Gavrilov, D., Komkov, A., Malinin, A. (2005). Innovative technology aimed at psychophysical diagnostic of students: methodological recommendations. St. Petersburg: NO-IFC, 264 p.

[9] Iyakrus 2012 Permainan Sepaktakraw (Palembang: Unpress Universitas Sriwijaya)

[10] Kwan, M.Y., Cairney, J., Faulkner, G.E., \& Pullenavegum, E.E. (2012). Physical activity and other health-risk behaviours during the transition into adulthood: A longitudinal cohort study. American Journal of Preventive Medicine, 42(1),14-20. Doi:10.1016/j.amepre.2011.08.026

[11] Maher, A. J. (2016). Special educational needs in mainstream secondary school physical education: learning support assistants have their say. Sport, Education and Society, 21, 262-278.

[12] Nurhasan 2009 Tes Dan Pengukuran Dalam Pendidikan Jasmani (Jakarta: Depdiknas)

[13] Pate R R 1990 Scientific Foundation of Coaching (New York: Saunders College Publishing)

[14] Sigmundova, D., Chmelik, F., Sigmund, E., Feltlova, D., \& Fromel, K. (2013). Physical 
activity in the lifestyle of Czech university students: Meeting health recommendations. European Journal of Sport Science, 13:6, 744-750. Doi:10.1080/17461.2013.776638

[15] Sofyan, Hanif 2011 Kepelatihan Dasar Sepaktakraw (Jakarta Timur: PT Bumi Timur Jaya)

[16] Sugiyono 2009 Metode Penelitian Kuantitatif, Kualititatif dan $R \& D$ (Bandung: Alfabeta)

[17] Trudeau, F., Shephard, R. (2010). Relationships of physical activity to brain health and the academic performance of schoolchildren. American journal of lifestyle medicine, 4(2), 138-150.

[18] Wahyu D 2004 Konsep Penelitian dan Pengembangan (Semarang: Universitas Negeri Semarang)

[19] Warburton, D.E.R., Nicol, C.W., Bredin, S.S.D. (2006) Health benefits of physical activity: the devidence. Review. CMAJ, 174(6):801809)

[20] Wasis, D. 2004 Konsep Penelitian dan Pengembangan (Malang: Lemblit UNM)

[21] Yatar, I.G., Oksuz, S., Yatar, I., Malkoc. M. (2015). The Comparison of Physical Activity and Health Related Physical Fitness Levels Between Exercising and Non-Exercising Housewives. International Journal of Basic and Clinical Studies (IJBCS), 4(1): 34-44. Online 2 December 2019. 